\title{
Racial Segregation as a Social Determinant of Health: Evidence from the State of Georgia
}

\author{
Simon Medcalfe, $\mathrm{PhD}^{1}$, Catherine P. Slade, $\mathrm{PhD}^{1}$, and Divesia Lee ${ }^{1}$ \\ ${ }^{1}$ James M. Hull College of Business, Augusta University, Augusta, GA \\ Corresponding Author: Catherine P. Slade, PhD • Professor, James M. Hull College of Business, Augusta University • 1120 15th St., Augusta, GA 30912 • \\ Telephone: (706) 667-4536•Email: cslade@augusta.edu
}

\section{ABSTRACT}

Background: Despite decades of research, determining the causes of racial disparities in health remains a pernicious problem in the public health arena. Challenges include further refining definitions of health as well as expanding frameworks for social determinants of health to include relevant and related predictors. Racial segregation as a social determinant of health is understudied but of growing interest in the discourse on health disparities. This paper explores empirically the relationship between racial segregation and other predictors of social determinants of health and their collective impact on health outcomes defined in both objective and subjective terms.

Methods: Ordinary least squares regression analysis was used to analyze health outcomes from the Robert Wood Johnson 2018 County Health Rankings for Georgia. At the county level we considered two distinct categories of health outcomes as the dependent variables, including objective measures of health status such as age-adjusted mortality and more subjective measures from the person's perspective of quality of life such self-reported health. The independent variables representing racial segregation included the black-white segregation and nonwhite-white segregation indices.

Results: Our findings are that racial segregation is not significantly associated with objective health outcome measures. Conversely and surprisingly, counties with higher levels of black-white and nonwhite-white segregation show better self-reported health. Control variables have the expected impact on health outcomes based on previous literature.

Conclusions: While segregation does not suggest poorer health status, the findings of higher quality of life assessment is concerning as a person's perspectives on their health predicts healthy behaviors and access to needed care. We suggest that racial segregation is an important addition to social determinants of health frameworks and models and worthy of continued multidisciplinary research on a national basis.

Keywords: Health outcomes, social determinants of health, racial disparities in health, racial segregation

\section{INTRODUCTION}

Racial disparities in health outcomes are of growing concern world-wide. Prior research on health outcomes has examined various predicting social factors such as health behaviors, clinical care, and the physical environment. More recent studies of health equity in particular have drawn attention to racial segregation or dissimilarity within communities (Iceland, Weinberg, and Steinmetz, 2002) and its impact on health outcomes (Gee and Ford, 2011). Residential segregation in general is increasingly considered an important factor in predicting both individual and community well-being, or lack thereof. Robert and Ruel (2006) for example summarize the robust literature that shows that racial segregation has been associated with higher rates of poverty, crime, high school dropout rates, unemployment, and lower rates of community participation.
These are the same variables considered in the racial disparities in health literature (AHRQ, 2019).

This study starts with a brief overview of the efforts to define health and health outcomes, followed by a discussion of a social determinants of health (SDOH) approach (Fazili, 2017) and the proposed role of racial segregation in this framework. Then we empirically evaluate county level data in the State of Georgia to test the relationship between racial residential segregation, using the dissimilarity indices, and other SDOH variables to predict health outcomes of two types, including objective measures of health status and more personal or subjective measures of quality of life. Our purpose is to build on prior racial disparities in health outcomes research which has a long history given its 
complexity. Our study is an important contribution as there are recent and mostly unexplained declines in US life expectancy, with notable racial, ethnic, and age differences in these declines being particularly concerning (The Economist NA, 2018; Kockanek et al., 2017). Efforts to address health disparities will be enhanced by continuing to identify and analyze social conditions shared by at-risk and vulnerable populations.

\section{Defining Health and Health Outcomes}

For decades the World Health Organization has defined health in a very broad sense and not merely as the absence of disease or premature death. Two broad categories of health and health outcomes have evolved to include: 1) health status or more objective biologic considerations with presence or absence of disease or signs of physical limitations; and 2) quality of life or a person's more subjective assessment of the impact of their physical condition on normal life (Currie, 2016; Fayers and Machin, 2000). As discussed in more detail below, most studies of racial segregation and health outcomes consider objective measures or subjective measures, with an emphasis on objective health status measures. Differences in the relationship between SDOH predictors and the two health outcome categories is important as the categories are related. A person's sense of their health or self-reported health predicts their approach to their health behaviors as well as use of important primary and preventive health services that could affect mortality, physical limitations, or disease (Anderson, 1995; Meurer, Layde, and Guse, 2001; Shi, Green, and Kazakova, 2004). We believe that our study is one of the first to make this important comparison, with the expectation that racial segregation should have the same relationship with both objective health status measures and subjective quality of life measures.

\section{Social Determinants of Health Outcomes}

The study of SDOH has evolved over time to include five to six dimensions. We use the Fazili (2017) adaptation from the Kaiser Family Foundation work (Artigi and Hinton, 2018; Heiman and Artigi, 2015) with a framework that includes the five dimensions of economic stability, neighborhood and physical environment, education, community and social context, and the health care system. In our framework, "food" is considered a variable within the economic stability category since hunger has been shown to be highly correlated with economic conditions Seligman and Schillinger, 2010). The impetus for our analysis is the ever growing research that indicates that developing expanded frameworks and models of the $\mathrm{SDOH}$, as well as focusing on health promotion and disease prevention initiatives, can result in reduced racial disparities in health (Blumenthal, 2016).

There is an interesting disconnect with respect to efforts to improve health outcomes, including reducing racial disparities. Socioeconomic factors have been shown to drive as much as fifty percent of health outcomes, however the U.S. healthcare system is not particularly well-designed to directly address and account for SDOH (Fazili, 2017). Social and structural forms of imbalanced social integration and discrimination exist and the relationship of these disparities to health inequities requires more study (Gee and Ford, 2011). This study builds on the previous and ongoing research on the community and social context aspect of $\mathrm{SDOH}$, specifically by addressing racial segregation, to identify potential new approaches to addressing health disparities. This effort is designed to broaden the base of evidence for new or enhanced policy to address mitigable social conditions like segregation that may exacerbate health inequities or institutionalized underserved populations based on race.

\section{Health Status Measures}

For the purpose of our study, we are interested in the two primary categories of health including health status and quality of life (Currie, 2016). We find that the bulk of racial segregation and health studies focus on health status or the more objective measures of health (Kramer and Hogue, 2009). For example, numerous studies have evaluated racial residential segregation with respect to specific health conditions such as STDs or sexually transmitted diseases (Biello et al, 2012; Thomas and Gaffield, 2003), access to diagnostic and surgical procedures (Skinner et. al 2003), and premature and low weight births (Kramer and Hogue, 2008; Nyarko and Wehby, 2011). The general findings are that racial segregation has adverse effects on these measures of health status.

The relationship between racial residential segregation and mortality among adults and infants is also the subject of much study in a variety of geographies and with variable definitions of mortality (Bird et al, 1995; Collins, 1999; Cooper et al, 2001; Hart et al., 1998; McFarland and Smith, 2011; Popescu, et al., 2018). The general finding is that some geographic areas are more prone to effects of racial segregation, the South and inner cities for example, and that racial segregation typically predicts higher levels of mortality. Poldenak's early research agenda on adult and infant mortality is of particular interest as it guided follow up research on racial segregation and health outcomes. In 1991 and 1996, Poldenak examined the black-white variance in infant mortality rates as it relates to socioeconomic factors and an index of residential segregation. He found that segregation was the only statistically significant independent predictor of the black-white difference in infant mortality rate among the metropolitan statistical areas studied, with blacks having a higher mortality rate. In similar research in 1993, Poldenak found that segregation was a significant predictor of adult mortality, but only when considering black men, with strong evidence of the influence of black male poverty in urban segregated areas. 


\section{Quality of Life Measures}

Subramanian, Acevedo-Garcia, and Osypuk (2005) find self-rated health is different from other measures of health status with respect to racial segregation and this is one impetus for our study. They suggest that racial segregation may not have a negative impact on self-rated health among blacks because it is not associated with a concentrated neighborhood disadvantage as much as it is neighborhood isolation. The discrepancy between the finding that dissimilarity is not significantly associated with poor self-rated health among blacks was noted by the authors as worthy of further study given that the previously reported aggregate relationship between dissimilarity and health outcomes may be an artifact of not accounting for important individual-level influences on health. Residential segregation may not be uniform for all categories of health outcomes where some are more objective, such as aggregated mortality rates for geographical regions, and some are more subjective such as self-reported health by individuals.

In summary the previous research presents a clear message that racial residential segregation should continue to be studied as a SDOH and that racial segregation does impact health outcomes differently for blacks and whites. The current study is motivated by gaps in previous research in that it compares the impact of racial segregation on both health status measures and quality of life measures, rather than one or the other category or variable within a category. The analysis of racial segregation and health at the county-level has also been understudied with previous work concentrating on urban areas or health services areas. Therefore, our research considers county-level characteristics for counties in the state of Georgia, a state recognized for public health concerns of this type (Csukas, 2014). Previous studies have found segregation is more prevalent in the South. Therefore Georgia is a prime state to analyze with respect to racial segregation and health outcomes.

\section{METHODS}

The 2018 County Health Rankings Georgia includes data for a variety of health outcomes and SDOH for counties in Georgia (University of Wisconsin, 2019). This data was organized through a collaboration between the Robert Wood Johnson Foundation and the University of Wisconsin Population Health Institute. Data is available for all 159 counties in Georgia. The health outcomes dependent variables are presented in two categories. The first category includes measures of health status or objective health measures including variables such as years of potential life lost (YPLL), low birthweight (LowBW) and age adjusted mortality (AAM). The second category includes quality of life measures or more subjective measures including the percentage reporting PoorFairHealth, the number of physically unhealthy days (PhysUnhealDys), and the number of days mental health was not good (MentUnhealDys).

The independent variables represent the social and economic factors dimension of the adapted Kaiser Family Foundation's Social Determinants of Health framework (Fazili, 2017; Heiman and Artigi, 2015) to include two measures of segregation, the black-white segregation index (BWSI), and the nonwhite-white segregation index (NWWSI). Segregation refers to the degree to which two or more groups, in the case races or racial categories, live separately from one another in a geographic area. The index of dissimilarity is a demographic measure of the evenness with which two groups (black and white residents, or non-white and white residents) are distributed across the component geographic areas (census tracts, in this case) that make up a larger area (counties, in this case). The index score can be interpreted as the percentage of either black or white residents that would have to move to different geographic areas in order to produce a distribution that matches that of the larger area (RWJ, 2019).

Control variables are categorized according to the other four dimensions of the adapted Kaiser Family Foundation SDOH (omitting access to healthy food options) framework (Fazili, 2017). These dimensions include economic stability, neighborhood and physical environment, healthcare system, and education. We also include county demographic characteristics. Variables were chosen for their explanatory contribution to the model and lack of multicollinearity. Descriptions of these variables and their summary statistics are provided in Table 1.

\section{RESULTS}

The data was analyzed using Stata Ordinary Least Squares regression modeling techniques with robust standard errors. Table 2 presents regression results for the measures of health status (objective) dependent variables and Table 3 presents the results for the quality of life (subjective) dependent variables. 
Table 1

Descriptive Statistics

\begin{tabular}{|c|c|c|c|c|}
\hline Dependent Variables & Description & $\mathbf{N}$ & Mean & SD \\
\hline YPLL & $\begin{array}{l}\text { Years Potential Life Lost Rate: Every death occurring before } \\
\text { the age of } 75 \text { contributes to the total number of YPLL. YPLL } \\
\text { is represented as a rate per } 100,000 \text { population and } \\
\text { age-adjusted to the } 2000 \text { US population. }\end{array}$ & 156 & 9101.556 & 1904.173 \\
\hline LowBW & $\begin{array}{l}\text { Low Birth Weight is the percentage of live births where the } \\
\text { infant weighed less than } 2,500 \text { grams (approximately } 5 \text { lbs., } 8 \\
\text { oz.) }\end{array}$ & 158 & 10.022 & 2.106 \\
\hline FairPoorHealth & $\begin{array}{l}\text { The percentage of adult respondents who rate their health } \\
\text { "fair" or "poor". }\end{array}$ & 159 & 20.086 & 3.988 \\
\hline PhysUnhealDys & $\begin{array}{l}\text { The average number of days a county's adult respondents } \\
\text { report that their physical health was not good during the past } \\
30 \text { days }\end{array}$ & 159 & 4.208 & 0.461 \\
\hline Independent Variables & Description & $\mathbf{N}$ & Mean & SD \\
\hline BWSI & Black/White Segregation Index & 150 & 30.756 & 14.457 \\
\hline NWWSI & Non-white/White Segregation Index & 155 & 27.087 & 12.712 \\
\hline Control Variables & Description & $\mathbf{N}$ & Mean & SD \\
\hline UE & $\begin{array}{l}\text { The percentage of the civilian labor force, age } 16 \text { and older, } \\
\text { that is unemployed but seeking work }\end{array}$ & 159 & 6.084 & 1.150 \\
\hline ViolentCrimeRate & $\begin{array}{l}\text { The number of violent crimes reported per } 100,000 \\
\text { population }\end{array}$ & 154 & 314.455 & 217.456 \\
\hline SHP & $\begin{array}{l}\text { The percentage of households with at least one or more of the } \\
\text { following housing problems: (1) housing unit lacks complete } \\
\text { kitchen facilities; (2) housing unit lacks complete plumbing } \\
\text { facilities; (3) household is severely overcrowded; or (4) } \\
\text { household is severely cost burdened. }\end{array}$ & 159 & 16.781 & 3.459 \\
\hline PCPRate & The ratio of the population to total primary care physicians & 146 & 47.347 & 28.003 \\
\hline MHPRate & The ratio of the population to total mental health providers & 136 & 69.103 & 72.337 \\
\hline GradRate & $\begin{array}{l}\text { The percentage of the ninth-grade cohort in public schools } \\
\text { that graduates from high school in four years }\end{array}$ & 149 & 83.861 & 7.464 \\
\hline SomeCollege & $\begin{array}{l}\text { The percentage of the population ages } 25-44 \text { with some } \\
\text { post-secondary education, such as enrollment in } \\
\text { vocational/technical schools, junior colleges, or four-year } \\
\text { colleges }\end{array}$ & 159 & 50.051 & 11.541 \\
\hline Asian & The percentage of the population that is Asian & 159 & 1.389 & 1.643 \\
\hline
\end{tabular}




\begin{tabular}{|c|c|c|c|c|}
\hline African American & The percentage of the population that is African American & 159 & 27.827 & 17.296 \\
\hline Native Hawaiian & $\begin{array}{l}\text { The percentage of the population that is Native Hawaiian } \\
\text { /Other Pacific Islander }\end{array}$ & 159 & 0.123 & 0.153 \\
\hline Female & The percentage of the population that is Female & 159 & 50.309 & 3.241 \\
\hline Logpop & Natural Log of Population & 159 & 10.193 & 1.205 \\
\hline
\end{tabular}

Table 2

Regression Results for Measures of Health Status

\begin{tabular}{|c|c|c|c|c|c|c|c|}
\hline \multirow[b]{2}{*}{$\underline{\text { Segregation Indexes }}$} & \multirow[b]{2}{*}{ BWSI } & \multicolumn{2}{|c|}{$\underline{\text { YPLL }}$} & \multicolumn{2}{|c|}{$\underline{\text { LowBW }}$} & \multicolumn{2}{|c|}{$\underline{\mathbf{A A M}}$} \\
\hline & & $\begin{array}{l}4.427 \\
(10.522)\end{array}$ & & $\begin{array}{l}0.006 \\
(0.009)\end{array}$ & & $\begin{array}{l}0.094 \\
(0.625)\end{array}$ & \\
\hline & NWWSI & & $\begin{array}{l}14.092 \\
(12.848)\end{array}$ & & $\begin{array}{l}0.012 \\
(0.012)\end{array}$ & & $\begin{array}{l}0.473 \\
(0.721)\end{array}$ \\
\hline \multirow[t]{3}{*}{ Economic } & $U E$ & $\begin{array}{l}414.56^{* *} \\
(185.612)\end{array}$ & $\begin{array}{l}395.86^{* *} \\
(175.467)\end{array}$ & $\begin{array}{l}0.24 \\
(0.203)\end{array}$ & $\begin{array}{l}0.20 \\
(0.196)\end{array}$ & $\begin{array}{l}24.6^{* * *} \\
(8.556)\end{array}$ & $\begin{array}{l}24.9^{* * *} \\
(8.405)\end{array}$ \\
\hline & IncRatio & $\begin{array}{l}173.393 \\
(225.045)\end{array}$ & $\begin{array}{l}222.523 \\
(199.857)\end{array}$ & $\begin{array}{l}-0.133 \\
(0.210)\end{array}$ & $\begin{array}{l}-0.040 \\
(0.208)\end{array}$ & $\begin{array}{l}14.827 \\
(10.554)\end{array}$ & $\begin{array}{l}20.73 * * \\
(9.736)\end{array}$ \\
\hline & Poverty & $\begin{array}{l}67.064 * \\
(35.136)\end{array}$ & $\begin{array}{l}59.213 \\
(33.752)\end{array}$ & $\begin{array}{l}0.09 * * * \\
(0.035)\end{array}$ & $\begin{array}{l}0.083 * * \\
(0.034)\end{array}$ & $\begin{array}{l}2.402 \\
(1.703)\end{array}$ & $\begin{array}{l}1.711 \\
(1.644)\end{array}$ \\
\hline \multirow{3}{*}{ 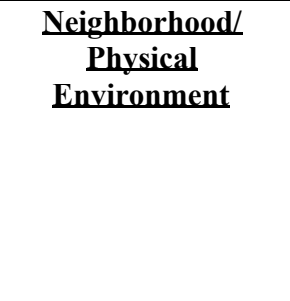 } & AccessExerc & $\begin{array}{l}-11.080 \\
(6.915)\end{array}$ & $\begin{array}{l}-11.745^{*} \\
(6.130)\end{array}$ & $\begin{array}{l}-0.010 \\
(0.007)\end{array}$ & $\begin{array}{l}-0.012 * \\
(0.006)\end{array}$ & $\begin{array}{l}-0.98 * * * \\
(0.344)\end{array}$ & $\begin{array}{l}-1.12 * * * \\
(0.323)\end{array}$ \\
\hline & ViolentCrime & $\begin{array}{l}0.8730 \\
(0.747)\end{array}$ & $\begin{array}{l}0.987 \\
(0.739)\end{array}$ & $\begin{array}{l}-0.000 \\
(0.000)\end{array}$ & $\begin{array}{l}-0.000 \\
(0.000)\end{array}$ & $\begin{array}{l}0.086^{* *} \\
(0.036)\end{array}$ & $\begin{array}{l}0.086^{* *} \\
(0.034)\end{array}$ \\
\hline & SHP & $\begin{array}{l}-6.408 \\
(51.690)\end{array}$ & $\begin{array}{l}-14.290 \\
(46.424)\end{array}$ & $\begin{array}{l}0.027 \\
(0.050)\end{array}$ & $\begin{array}{l}0.011 \\
(0.048)\end{array}$ & $\begin{array}{l}-2.651 \\
(2.695)\end{array}$ & $\begin{array}{l}-3.369 \\
(2.343)\end{array}$ \\
\hline \multirow[t]{2}{*}{ Education } & GradRate & $\begin{array}{l}-0.772 \\
(20.7473)\end{array}$ & $\begin{array}{l}-0.292 \\
(19.8050)\end{array}$ & $\begin{array}{l}0.003 \\
(0.0264)\end{array}$ & $\begin{array}{l}0.004 \\
(0.0260)\end{array}$ & $\begin{array}{l}0.079 \\
(0.9660)\end{array}$ & $\begin{array}{l}-0.075 \\
(0.9512)\end{array}$ \\
\hline & SomeCollege & $\begin{array}{l}-36.803 \\
(24.347)\end{array}$ & $\begin{array}{l}-38.125^{*} \\
(22.426)\end{array}$ & $\begin{array}{l}-0.011 \\
(0.019)\end{array}$ & $\begin{array}{l}-0.012 \\
(0.018)\end{array}$ & $\begin{array}{l}-2.095^{*} \\
(1.144)\end{array}$ & $\begin{array}{l}-1.995^{*} \\
(1.060)\end{array}$ \\
\hline \multirow[t]{2}{*}{ Healthcare } & PCPRate & $\begin{array}{l}4.252 \\
(4.943)\end{array}$ & $\begin{array}{l}1.819 \\
(4.991)\end{array}$ & $\begin{array}{l}0.007 \\
(0.004)\end{array}$ & $\begin{array}{l}0.004 \\
(0.005)\end{array}$ & $\begin{array}{l}0.005 \\
(0.233)\end{array}$ & $\begin{array}{l}-0.141 \\
(0.234)\end{array}$ \\
\hline & MHPRate & $\begin{array}{l}-0.077 \\
(1.506)\end{array}$ & $\begin{array}{l}0.225 \\
(1.467)\end{array}$ & $\begin{array}{l}-0.003^{*} \\
(0.001)\end{array}$ & $\begin{array}{l}-0.002 * \\
(0.001)\end{array}$ & $\begin{array}{l}0.034 \\
(0.069)\end{array}$ & $\begin{array}{l}0.047 \\
(0.064)\end{array}$ \\
\hline \multirow[t]{3}{*}{$\begin{array}{c}\text { County } \\
\text { Characteristics }\end{array}$} & Asian & $\begin{array}{l}-170.93 * * * \\
(60.20)\end{array}$ & $\begin{array}{l}-164.44 * * \\
* \\
(56.19)\end{array}$ & $\begin{array}{l}-0.041 \\
(0.059)\end{array}$ & $\begin{array}{l}-0.044 \\
(0.057)\end{array}$ & $\begin{array}{l}-9.63 * * * \\
(2.944)\end{array}$ & $\begin{array}{l}-10.04 * * * \\
(2.90)\end{array}$ \\
\hline & African American & $\begin{array}{l}-18.548 \\
(11.589)\end{array}$ & $\begin{array}{l}-18.113^{*} \\
(10.595)\end{array}$ & $\begin{array}{l}0.039 * * * \\
(0.014)\end{array}$ & $\begin{array}{l}0.042 * * * \\
(0.013)\end{array}$ & $\begin{array}{l}-1.297 * * \\
(0.584)\end{array}$ & $\begin{array}{l}-1.027 * * \\
(0.509)\end{array}$ \\
\hline & Hispanic & -33.716 & -36.419 & $-0.059^{*}$ & $-0.054^{*}$ & -2.108 & -1.461 \\
\hline
\end{tabular}




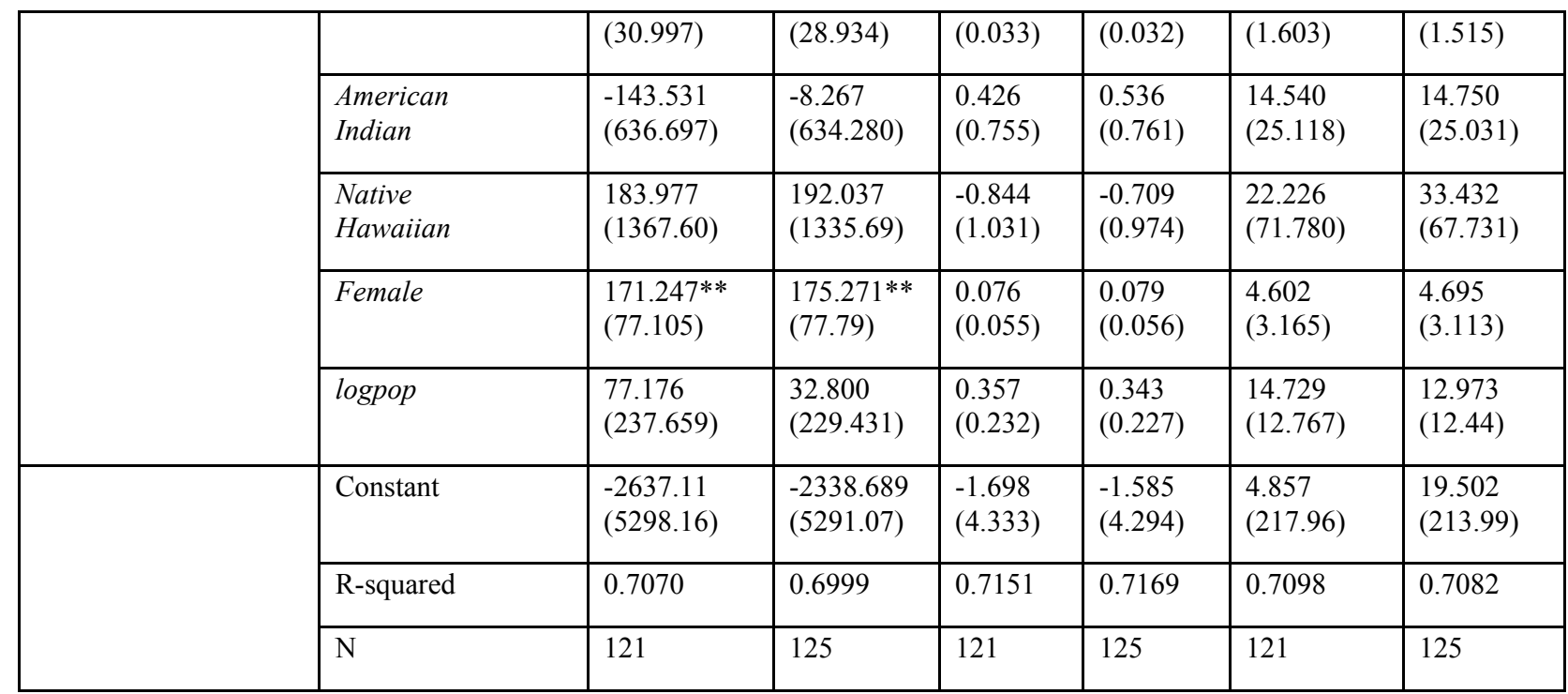

Note: robust standard error in parentheses for all tables. ${ }^{* * *} \mathrm{p}<0.01, * * \mathrm{p}<0.05$, and $* \mathrm{p}<0.1$

Table 3

Regression Results for Quality of Life Measures

\begin{tabular}{|c|c|c|c|c|c|c|c|}
\hline \multirow[b]{2}{*}{ Segregation Indexes } & \multirow[b]{2}{*}{ BWSI } & \multicolumn{2}{|c|}{ FairPoorHealth } & \multicolumn{2}{|c|}{ PhysUnhealDys } & \multicolumn{2}{|c|}{ MentUnhealDys } \\
\hline & & $\begin{array}{l}-0.032 * * * \\
(0.012)\end{array}$ & & $\begin{array}{l}-0.005^{* * * *} \\
(0.002)\end{array}$ & & $\begin{array}{l}-0.002 * * \\
(0.001)\end{array}$ & \\
\hline & NWWSI & & $\begin{array}{l}-0.029 * * \\
(0.013)\end{array}$ & & $\begin{array}{l}-0.005^{* * * *} \\
(0.002)\end{array}$ & & $\begin{array}{l}-0.002 * * \\
(0.001)\end{array}$ \\
\hline \multirow[t]{3}{*}{ Economic } & $U E$ & $\begin{array}{l}0.392 * \\
(0.230)\end{array}$ & $\begin{array}{l}0.393^{*} \\
(0.215)\end{array}$ & $\begin{array}{l}0.025 \\
(0.032)\end{array}$ & $\begin{array}{l}0.0280 \\
(0.030)\end{array}$ & $\begin{array}{l}0.010 \\
(0.020)\end{array}$ & $\begin{array}{l}0.013 \\
(0.019)\end{array}$ \\
\hline & IncRatio & $\begin{array}{l}0.625 * * \\
(0.307)\end{array}$ & $\begin{array}{l}0.813 * * * \\
(0.275)\end{array}$ & $\begin{array}{l}0.100 * * \\
(0.042)\end{array}$ & $\begin{array}{l}0.124 * * * \\
(0.037)\end{array}$ & $\begin{array}{l}0.064 * * \\
(0.030)\end{array}$ & $\begin{array}{l}0.078 * * * \\
(0.026)\end{array}$ \\
\hline & Poverty & $\begin{array}{l}0.186^{* * * *} \\
(0.034)\end{array}$ & $\begin{array}{l}0.165^{* * *} \\
(0.275)\end{array}$ & $\begin{array}{l}0.0270 * * * \\
(0.005)\end{array}$ & $\begin{array}{l}0.024 * * * \\
(0.005)\end{array}$ & $\begin{array}{l}0.016^{* * *} \\
(0.004)\end{array}$ & $\begin{array}{l}0.015 * * * \\
(.003)\end{array}$ \\
\hline \multirow[t]{3}{*}{$\begin{array}{c}\text { Neighborhood/ } \\
\text { Physical Environment }\end{array}$} & AccessExerc & $\begin{array}{l}-0.002 \\
(0.008)\end{array}$ & $\begin{array}{l}-0.008 \\
(0.008)\end{array}$ & $\begin{array}{l}-0.000 \\
(0.001)\end{array}$ & $\begin{array}{l}-.001 \\
(0.001)\end{array}$ & $\begin{array}{l}-0.001 \\
(0.001)\end{array}$ & $\begin{array}{l}-0.001 \\
(0.001)\end{array}$ \\
\hline & ViolentCrime & $\begin{array}{l}-0.002 \\
(0.001)\end{array}$ & $\begin{array}{l}-0.002 \\
(0.001)\end{array}$ & $\begin{array}{l}-0.000 \\
(0.000)\end{array}$ & $\begin{array}{l}-0.000 \\
(0.000)\end{array}$ & $\begin{array}{l}-0.000 \\
(0.000)\end{array}$ & $\begin{array}{l}-0.000 \\
(0.000)\end{array}$ \\
\hline & SHP & $\begin{array}{l}0.172 * * * \\
(0.062)\end{array}$ & $\begin{array}{l}0.128 * * \\
(0.056)\end{array}$ & $\begin{array}{l}0.018 * * \\
(0.008)\end{array}$ & $\begin{array}{l}0.012 \\
0.008\end{array}$ & $\begin{array}{l}0.012 * \\
(0.006)\end{array}$ & $\begin{array}{l}0.010^{*} \\
(0.006)\end{array}$ \\
\hline \multirow[t]{2}{*}{ Education } & GradRate & $\begin{array}{l}0.033 \\
(0.025\end{array}$ & $\begin{array}{l}0.024 \\
(0.025)\end{array}$ & $\begin{array}{l}0.005 \\
(0.003)\end{array}$ & $\begin{array}{l}0.003 \\
(0.003)\end{array}$ & $\begin{array}{l}0.004^{*} \\
(0.002)\end{array}$ & $\begin{array}{l}0.003 \\
(0.002)\end{array}$ \\
\hline & SomeCollege & $\begin{array}{l}-0.025 \\
(0.022)\end{array}$ & $\begin{array}{l}-0.025 \\
(0.021)\end{array}$ & $\begin{array}{l}-0.007 * * \\
(0.003)\end{array}$ & $\begin{array}{l}-0.006^{* *} \\
(0.003)\end{array}$ & $\begin{array}{l}-0.003 \\
(0.002)\end{array}$ & $\begin{array}{l}-0.003 \\
(0.002)\end{array}$ \\
\hline \multirow[t]{2}{*}{ Healthcare } & PCPRate & $\begin{array}{l}-0.004 \\
(0.006)\end{array}$ & $\begin{array}{l}-0.006 \\
(0.006)\end{array}$ & $\begin{array}{l}-0.000 \\
(0.001)\end{array}$ & $\begin{array}{l}-0.001 \\
(0.001)\end{array}$ & $\begin{array}{l}-0.001 \\
(0.001)\end{array}$ & $\begin{array}{l}-0.001 \\
(0.001)\end{array}$ \\
\hline & MHPRate & $\begin{array}{l}-0.001 \\
(0.002)\end{array}$ & $\begin{array}{l}-0.001 \\
(0.002)\end{array}$ & $\begin{array}{l}0.000 \\
(0.000)\end{array}$ & $\begin{array}{l}0.000 \\
(0.000)\end{array}$ & $\begin{array}{l}0.000 \\
(0.000)\end{array}$ & $\begin{array}{l}0.000 \\
(0.000)\end{array}$ \\
\hline $\begin{array}{c}\text { County } \\
\text { Characteristics }\end{array}$ & Asian & $\begin{array}{l}-0.183 \\
(0.113)\end{array}$ & $\begin{array}{l}-0.208^{*} \\
(0.120)\end{array}$ & $\begin{array}{l}-0.035^{* * *} \\
(0.010)\end{array}$ & $\begin{array}{l}-0.039 * * * \\
(0.010)\end{array}$ & $\begin{array}{l}-0.044 * * * \\
(0.009)\end{array}$ & $\begin{array}{l}-0.046^{* * *} \\
(0.009)\end{array}$ \\
\hline
\end{tabular}




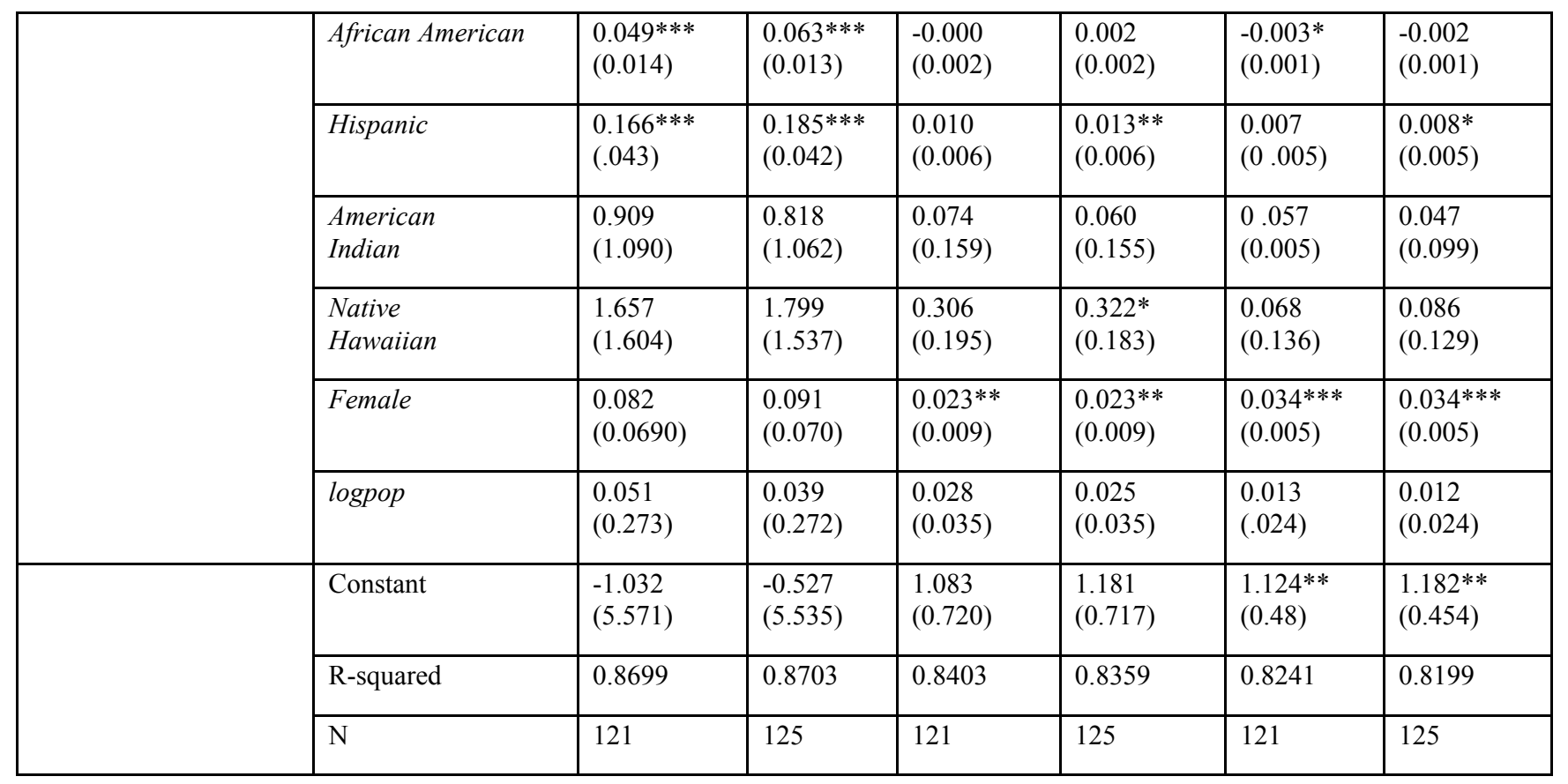

Note. Robust standard error in parentheses for all tables. $* * * \mathrm{p}<0.01, * * \mathrm{p}<0.05$, and $* \mathrm{p}<0.1$

Our main variables of interest, the segregation indexes, are never significant determinants of health status as seen in Table 2. However, when looking at the quality of life outcomes in table 3 , the segregation indexes are always negative and significant. This suggests that more segregated counties have fewer percentage reporting various aspects of poor health. The coefficients suggest that an increase in the segregation indices by 10 points will decrease the percentage reporting FairPoorHealth by 0.3 percentage points. A 10 point increase in the segregation indices will decrease the number of reported physically unhealthy days by about half a day a year and about a quarter of a day for mentally unhealthy days. Given the average population of a county in Georgia is 65,000 this equates to over 30,000 physically unhealthy days and over 16,000 mentally unhealthy days per year.

The SDOH that have the most impact on quality of life outcomes are economic stability and neighborhood and physical environment. Higher rates of both income ratio and poverty are consistently associated with higher reporting of FairPoorHealth and physically and mentally unhealthy days. Severe housing problems are also associated with higher self-reporting of FairPoorHealth and unhealthy days. Demographics of the county are also important. As the percentage of Asians in a county increases, there is improvement in the quality of life measures. Larger Hispanic, and to a lesser extent African-American, populations will increase self-reporting of FairPoorHealth and unhealthy days. A larger female population is associated with higher reporting of physical and mentally unhealthy days.
The control variables for measures of health status tell a different story. Here, all the major categories of the SDOH have an impact on health status in at least one model. Higher unemployment rates are associated with increases in YPLL and AAM. Poverty has a positive association with the percentage of births that have low birth weights. Increased access to exercise is generally associated with better health outcomes. Violent crime, unsurprisingly, increases AAM. There is some evidence that more educated people with some college have better health outcomes. Surprisingly, as population per mental health provider increases the percent of low weight births decreases. Demographics are also important where counties with higher Asian populations have lower YPLL and AAM. A larger African American population is associated with lower YPLL and AAM but higher low birth weight whereas a larger Hispanic population is associated with a lower percentage of low birth weight. Interestingly, the primary care provider rate is never statistically significant in any of our regressions for health outcomes or quality of life measures indicating the importance of other SDOH.

\section{DISCUSSION}

Racial residential segregation was found to have a significant and negative relationship with subjective quality of life outcomes but had no effect on objective measures of health status. This result has important implications for public health and future research. If self-reported health is predictive of morbidity and mortality, independently, why do these differences occur, particularly given that how people view and experience their own general health predicts their need to behave in a certain way including pursuing health behaviors or preventive care (Anderson, 
1995, Babitsch, Gohl, and von Lengerke, 2012)? Analysis of individual level data may determine the cause of the disparate effect of segregation on health outcomes. Public health policy may consider the most appropriate ways to mitigate the effects of segregation, for example, through health education, a focus on eliminating built environment disparities (Hutch et al., 2011), or more drastic policies similar to the Moving To Opportunity project which has seen improvements in socioeconomic conditions for families randomly selected to move from high poverty neighborhoods (Chetty, Hendren, and Katz, 2016).

As expected the important determinants of health outcomes, controlling for racial segregation, are factors like unemployment, poverty, and education. Based on these results, it seems that policy makers would do well to continue efforts to improve economic prosperity and education systems to result in better health status.

\section{CONCLUSIONS AND FUTURE DIRECTION}

Racial segregation has been of growing interest as a SDOH. Previous research has concentrated on understanding the relationship between objective measures of health status and racial segregation and has been concentrated in urban areas. Using a dataset on all counties in Georgia and several measures of subjective and objective health outcomes we find that racial segregation is significantly associated with better self-reported health but not health status. Our results indicate that racial segregation may warrant inclusion as a $\mathrm{SDOH}$, particularly when addressing quality of life measures that predict healthy behaviors and access to and use of primary and preventive health care services.

The purpose of our study is to not only continue the theoretical and analytical exploration of relationship between racial segregation as a social determinant of health disparities. We also intend to continue to engage the community and policy makers in informed discussion of the pernicious issue of racial health inequities. Communities at large are perplexed by health inequities. For example, a fairly recent article in the Augusta Chronicle (February 17, 2019), posed the question, "how is a city [Augusta, Georgia] positively crawling with physicians end up ranked as one of America's unhealthiest?". Our research helps answer that question by demonstrating that health status is often socially determined well before healthcare services are sought. In another example, our research responds to state policy makers, such as the Georgia House of Representatives Study Committee on Maternal Mortality (House Budget and Research Office, 2019, p. 12) call for "continued research on racial disparity, social determinants of health, and genetics to further understand and prevent maternal mortality". Our research addresses this challenge by showing that the relationship between racial segregations and health disparities is only part of the complex interrelationship of social determinants, certainly worthy of continued research to address community stakeholder concerns.

One limitation of this study was the absence of statistical data for certain social determinants of health in different counties in the state of Georgia. In addition our findings call for more policy-targeted research analyzing the relationship between racial segregation and health outcomes, considering the complex differences in categories of health outcomes (subjective versus objective) in different levels of geography (counties within states within the US). This challenge may be addressed with a broader geography, more sophisticated multilevel geographic analysis, and a larger and richer data set. Motivated by our highly relevant findings in the State of Georgia, we are now engaged in further study of the relationship between racial segregation, a mitigable social determinant of health, and health inequities.

\section{References}

AHRQ. National Healthcare Quality and Disparities Report: Introduction and Methods. Rockville, MD: Agency for Healthcare Research and Quality; 2019. AHRQ Publication No. 19-0070-EF.

Andersen, R. Revisiting the behavioral model and access to medical care: does it matter? J HEALTH SOC BEHAV. 1995; $1-10$.

Artiga, S., Hinton, E. (2018). Beyond Health Care: The Role of Social Determinants in Promoting Health and Health Equity. Kaiser Family Foundation, 1995.

https://www.kff.org/disparities-policy/issue-brief/beyond-healthcare-the-role-of-social-determinants-in-promoting-health-and-he alth-equity/. Accessed October 15, 2019.

Augusta Chronicle (2019, February 17). Editorial - Good News and Bad News. The Augusta Chronicle, Augusta, Georgia. https://www.augustachronicle.com/opinion/20190217/editorial-g ood-news-and-bad-news. Accessed May 18, 2020.

Babitsch B, Gohl D, von Lengerke T. Re-revisiting Andersen's Behavioral Model of Health Services Use: a systematic review of studies from 1998-2011. PSYCHOSOC MED. 2012;9: Doc11. doi:10.3205/psm000089

Biello, K., et al. Racial residential segregation and rates of gonorrhea in the United States, 2003-2007. AM J PUB HEALTH. 2012; 102(7):1370-1377.

Bird, S. Separate black and white infant mortality models: Differences in the importance of structural variables. SOC SCI MED. 1995; 41(11):1507-1512.

Blumenthal, D. S. Reducing and eliminating health disparities through prevention and public health. jGPHA. 2016;6(1):3-6.

Chetty, R., Hendren, H., Katz, L. The effects of exposure to better neighborhoods on children: New evidence from the Moving to Opportunity project. AM ECON REV. 2016;106 (4):855-902.

Collins, C. Racism and health: Segregation and causes of death amenable to medical intervention in major U.S. cities. ANN NY ACAD SCI. 1999;896(1):396-398.

Cooper, R. Relationship between premature mortality and socioeconomic factors in black and white populations of US metropolitan areas. PUBLIC HEALTH REP. 2001;116(5):464-473.

Currie, C. Measures of health status, quality of life, and health care. HealthKnowledge.org.uk.

https://www.healthknowledge.org.uk/public-health-textbook/res earch-methods/1c-health-care-evaluation-health-care-assessment /measures-health-status. Accessed October 15, 2019. 
Csukas, S. Making Georgia healthy from the start. Georgia Department of Public Health, 2014.

https://dph.georgia.gov/blog/2014-04-07/making-georgia-health y-start. Accessed October 15, 2019.

Fazili, S. Can community development improve health? Emerging opportunities for collaboration between the health and community development sectors. FRB Atlanta Community and Economic Development Discussion Paper No. 2017-3. https://ssrn.com/abstract=3092550. Accessed October 15, 2019.

Fayers, P. M., Machin, D. Quality of life: The assessment, analysis and interpretation of patient-reported outcomes. John Wiley \& Sons. 2013.

Gee, G., Ford, C. Structural racism and health inequities. Du Bois Review: Social Science Research on Race. 2011;8(1):115-132.

Hart, K., et al. Metropolitan governance, residential segregation, and mortality among African Americans. AM J PUBLIC HEALTH. 1998;88(3);434-438.

Heiman, H.J., Artiga. S. (2015). Beyond Health Care: The Role of Social Determinants in Promoting Health and Health Equity. The Henry J. Kaiser Family Foundation, 2015. https://pdfs.semanticscholar.org/5850/c7fd80fd5dbff6930a253ae 2c700d3b21640.pdf. Accessed October 15, 2019.

House Budget \& Research Office (2019). State of Georgia House of Representatives Study Committee on Maternal Mortality. http://www.house.ga.gov/Documents/CommitteeDocuments/201 9/MaternalMortality/HR_589_Final_Report.pdf. Accessed May 18, 2020.

Hutch, Daniel J., et al. Potential strategies to eliminate built environment disparities for disadvantaged and vulnerable communities. AM J PUB HEALTH. 2011;101(4):587-595.

Iceland, J., Weinberg, D.H., Steinmetz, E. U.S. Census Bureau, Series CENSR-3, Racial and Ethnic Residential Segregation in the United States: 1980-2000. U.S. Government Printing Office, Washington, DC, 2002.

https://www.census.gov/prod/2002pubs/censr-3.pdf. Accessed October 15, 2019.

Kramer, M., Hogue, C. Is segregation bad for your health? EPIDEMIOL REV. 2009;31(1): 178-194.

Kramer, M., Hogue, C. Place matters: Variation in the Black/White Very Preterm Birth Rate across U.S. metropolitan areas, 2002-2004." PUBLIC HEALTH REP. 2008;123(5):576-585.

Kochanek KD, Murphy SL, Xu JQ, Arias E. Mortality in the United States, 2016. NCHS Data Brief, no 293. Hyattsville, MD: National Center for Health Statistics. 2017.

The Economist NA. Life Expectancy in America Has Declined for Two Years in a Row. The Economist Newspaper, 4 Jan. 2018. https:/www.economist.com/united-states/2018/01/04/life-expect ancy-in-america-has-declined-for-two-years-in-a-row. Accessed October 15, 2019.

McFarland, M., Smith, C. Segregation, race, and infant well-being. POPUL RES POLICY REV. 2011;30(3):467-493.
Meurer, L., Layde, P., Guse, C. Self-rated health status: A new vital sign for primary care? MED J WISCONSIN. 2001;100(7):35-39

Nyarko, K., Wehby, G. Residential segregation and the health of African-American infants: Does the effect vary by prevalence? MATERN CHILD HLTH J. 2011;16(7):1491-1499.

Polednak, A . Black-white differences in infant mortality in 38 standard metropolitan statistical areas. AM J PUBLIC HEALTH. 1991;81(11):1480-1482.

Polednak, A. Poverty, residential segregation, and Black/White mortality ratios in urban areas. Journal of Health Care for the Poor and Underserved. 1993;4(4):363-373.

Polednak, A. Trends in US urban black infant mortality, by degree of residential segregation. AM J PUBLIC HEALTH. 1996;86(5):723-726.

Popescu, I. et al. Racial residential segregation, socioeconomic disparities, and the White-Black survival gap. PLOS ONE. 2018;13(2).

Robert, S., Ruel, E. Racial segregation and health disparities between Black and White older adults. J GERONTOL. 2006;61B(4):S203-S211.

RWJ Robert Wood Johnson. Racial Segregation - Black-White in County Health Rankings \& Roadmaps. Robert Wood Johnson Foundation.

https://www.countyhealthrankings.org/explore-health-rankings/ measures-data-sources/county-health-rankings-model/health-fact ors/social-and-economic-factors/family-social-support/residentia l-segregation-blackwhite. Accessed October 15, 2019.

Seligman, H., Schillinger, D. Hunger and socioeconomic disparities in chronic disease. N ENGL J MED. 2010;363(1): 6-9.

Shi, L., Green, L. H., Kazakova, S. (2004). Primary care experience and racial disparities in self-reported health status. J AM BOARD FAM PRACT. 2004;17(6):443-452.

Skinner, J. et al. Racial, ethnic, and geographic disparities in rates of knee arthroplasty among Medicare patients. NEW ENGL J MED. 2003;349(14):1350-1359.

Subramanian, S. et al. Racial residential segregation and geographic heterogeneity in Black/White disparity in poor self-rated health in the US: a multilevel statistical analysis. SOC SCI MED. 2005;60(8):1667-1679.

Thomas, J. and M. Gaffield. Social structure, race, and gonorrhea rates in the Southeastern United States. ETHNIC DIS. 2003;13(3):362-368.

University of Wisconsin Population Health Institute. County Health Rankings Key Findings 2018. https://www.countyhealthrankings.org/reports/2018-county-heal th-rankings-key-findings-report. Accessed October 15, 2019.

(C) Simon Medcalfe, Catherine P. Slade, and Divesia Lee. Originally published in jGPHA (http://www.gapha.org/jgpha/) July 24, 2020. This is an open-access article distributed under the terms of the Creative Commons Attribution Non-Commercial No-Derivatives License (http://creativecommons.org/licenses/by/4.0), which permits unrestricted use, distribution, and reproduction in any medium, provided the original work ("first published in the Journal of the Georgia Public Health Association...") is properly cited with original URL and bibliographic citation information. The complete bibliographic information, a link to the original publication on http://www.gapha.jgpha.org/, as well as this copyright and license information must be included. 